\title{
DARIA HEJWOSZ-GROMKOWSKA
}

Uniwersytet im. Adama Mickiewicza

w Poznaniu

\section{MŁODZIEŻ, FACEBOOK A PROBLEM PARTYCYPACJI SPOŁECZNEJ}

ABSTRACT. Hejwosz-Gromkowska Daria, Młodzież, Facebook a problem partycypacji społecznej [Youth, Facebook and Social Participation]. Studia Edukacyjne nr 35, 2015, Poznań 2015, pp. 179-198. Adam Mickiewicz University Press. ISBN 978-83-232-2904-9. ISSN 1233-6688. DOI: 10.14746/se.2015.35.10

Over the past decade, Facebook and Internet-based technologies have become a central part in the social lives of many young people around the world. Social network sites such as Facebook are often conceived of as purely social spaces while there is growing evidence that they may serve as a powerful tool in communication and creating digital citizenship. Moreover, studies show that Facebook can be used in mobilising social participation. In this paper I will try to answer the following questions: does Facebook help make good citizens? Does it help to understand democracy? Is Facebook a real or only a virtual community? How to work with students to give them clear guidelines on how to be responsible digital citizens?

Key words: Facebook, social participation, community, youth

Kilkanaście lat temu na gruncie polskiej socjologii kultury profesor Zbyszko Melosik upowszechnił kategorię kultury typu instant. W swoich analizach tego fenomenu kulturowego zauważa, że charakteryzuje się on nawykiem i koniecznością życia w natychmiastowości, a jego „symbolem jest słynna triada "Fast food, Fast sex, Fast car"1. Jest ona również nieodłączną częścią ideologii konsumpcji, która stała się „wielką narracją” współczesnego społeczeństwa². Należy również zauważyć za Beniaminem Barberem, że

\footnotetext{
1 Z. Melosik, Teoria i praktyka edukacji wielokulturowej, Kraków 2007, s. 33.

2 Tamże.
} 
współczesne społeczeństwa charakteryzuje obsesja na punkcie prędkości ${ }^{3}$. Niewątpliwie, zjawisko przyspieszenia społecznego jest pochodną rozwoju technologii. Szczególne znaczenie ma w tym zakresie Internet. Można postawić tezę, iż współczesna młodzież jest w permanentnym kontakcie ze sobą, dzięki mobilnym urządzeniom. Ujmując to metaforycznie, staje się ona pokoleniem "wireless" (bezprzewodowym). Doskonałą egzemplifikacją społecznej akceleracji, kultury natychmiastowości, globalizacji i permanentnej wirtualnej styczności jednostek jest portal społecznościowy Facebook. Warto również zauważyć, iż wielu badaczy przedmiotu dowodzi, iż medium to może być także wykorzystywane $\mathrm{w}$ procesie dydaktycznym zarówno w szkolnictwie wyższym, jak i na niższych szczeblach edukacji. Fenomen Facebooka stał się przedmiotem badań przedstawicieli różnych dyscyplin naukowych; na jego temat powstają dysertacje, monografie książkowe oraz liczne artykuły4. Zarówno badacze tego zjawiska, jak i obserwatorzy życia społecznego wykazują postawy ambiwalentne - od zachwytu, poprzez sceptycyzm, na negatywnej opinii skończywszy.

Celem niniejszej pracy jest próba znalezienia odpowiedzi na pytanie odnośnie relacji między Facebookiem a społeczną partycypacją młodzieży. Czy portal ten może być postrzegany jako współczesna agora kształtowania postaw obywatelskich? Czy może być źródłem wiedzy i inspiracji do działań na rzecz demokracji? Czy można postrzegać go w kategoriach wspólnoty? A może przeciwnie, należy postrzegać go jedynie jako przykład trywializacji demokracji i postaw obywatelskich oraz jako wspólnotę konsumentów?

\section{Młodzież w czasach społecznej akceleracji i globalizacji}

Niemiecki socjolog Hartmut Rosa zauważa, że „doświadczenie nowoczesności jest doświadczeniem przyspieszenia" ${ }^{5}$. Społeczna akceleracja oraz kultura natychmiastowości sprowadza zjawisko „spowolnienia” do katego-

\footnotetext{
${ }^{3}$ B. Barber, Skonsumowani, Jak rynek psuje dzieci, infantylizuje dorostych i potyka obywateli, Warszawa 2008

4 Por. m.in. C. Lampe i in., Student use of Facebook for organizing collaborative classroom activities, Computer-Supported Collaborative Learning, 2011, 6, s. 329-347; R.L. Freishtat, J.A. Sandlin, Shaping Youth Discourse About Technology: Technological Colonization, Manifest Destiny, and the Frontier Myth in Facebook's Public Pedagogy, Educational Studies, 2010, 46, s. 503-523; Z. Melosik, Kultura popularna i tożsamość młodzieży. W niewoli władzy i wolności, Kraków 2013; D. Hejwosz-Gromkowska (red.), Rekonstrukcje tożsamości w kulturze natychmiastowości, Poznań 2014.

${ }^{5}$ H. Rosa, Social acceleration. A New theory of modernity, przekł. J. Trejo-Methys, New YorkChichester-West Sussex 2013, s. 21.
} 
rii patologicznej. Presja kulturowa na bycie w ciągłym ruchu powoduje u współczesnej generacji lęk przed "niedotrzymaniem kroku” 6 zarówno w sferze życia towarzyskiego, jak i kariery zawodowej. Portale społecznościowe, takie jak Facebook czy Twitter, umożliwiają „utrzymanie” właściwego tempa życia towarzyskiego. Zygmunt Bauman analizując zjawisko globalizacji, twierdzi, że społeczeństwo dzieli się na ludzi w pełni "globalnych" oraz na tych, którzy utkwili w swojej „lokalności”. Ci drudzy, w świecie, którym rządzą jednostki zglobalizowane, świecie, rozumianym jako mobilny, „lokalność jest oznaką społecznego upośledzenia i degradacji" 7 . Nie dziwi zatem fakt, że współczesna młodzież, która nie chce „utkwić" w swej lokalności musi być w pełni mobilna. Ta mobilność daje gwarancję nie tylko utrzymania więzi towarzyskich, ale także znalezienia pracy, awansu zawodowego i społecznego. Posiadanie wirtualnej skrzynki pocztowej, telefonu komórkowego (gwarantującego permanentną gotowość do działania) stało się wymogiem współczesnego mobilnego świata. Dla młodych ludzi założenie konta na profilu społecznościowym, jakim jest właśnie Facebook, ma uchronić ich przed „śmiercią" towarzyską i społecznym wykluczeniem.

Facebook do pewnego stopnia stał się urzeczywistnieniem McLuhanowskiej "globalnej wioski”. Marshall McLuhan okazał się wizjonerem, bowiem przewidział, że na skutek rozwoju technik komunikacyjnych nastąpi kompresja czasu i przestrzeni. I tak też się stało. Oto bowiem w dwudziestym pierwszym wieku, bez wychodzenia z domu, za pomocą kilku kliknięć na klawiaturze komputera, ludzie mogą komunikować się ze sobą, mimo iż fizycznie oddzielają ich setki tysięcy kilometrów. Mogą robić zakupy, przeglądać międzynarodowe czasopisma, odwiedzać biblioteki uczelni na całym świecie, a nawet ukończyć uniwersytet. Ponadto, w ciągu kilku minut dowiadują się o gwałtownych spadkach notowań na giełdzie w Nowym Jorku, konflikcie zbrojnym w Syrii lub na Ukrainie. Mogą na żywo - ciągle nie wychodząc z domu - obserwować wydarzenia na Alasce, w Australii, czy gdziekolwiek indziej na Ziemi. Wystarczy sprzęt komputerowy (w dzisiejszych czasach już tylko telefon komórkowy) i dostęp do sieci internetowej. Współczesne życie toczy się równolegle w świecie realnym i wirtualnym, można by rzec - mamy życie i e-życie.

Myliłby się ten, kto uważa, że procesy globalizacyjne dzieją się "gdzieś tam" i nie mają wpływu na codzienne życie ludzi. Bowiem jak zauważa Anthony Giddens:

${ }^{6}$ Tamże, s. 75; por. także Z. Melosik, Kultura popularna i tożsamość młodzieży.

7 Z. Bauman, Globalizacja. I co z tego dla ludzi wynika, Warszawa 1999, s. 7. 
globalizacja to zjawisko rozgrywające się "tutaj”, które wpływa na najbardziej intymne aspekty naszego życia (czy raczej jest z nimi w dialektyczny sposób powiązane). Można wręcz powiedzieć, że to, co nazywamy obecnie intymnością i jej znaczeniem w stosunkach międzyludzkich, jest dziś w dużym stopniu wytworem zjawisk globalnych 8 .

Żyjemy w ,jednym świecie”, w którym jednostki, grupy oraz całe narody są od siebie wzajemnie uzależnione. W ten sposób można najkrócej opisać zjawisko globalizacji. Przez pewien czas było ono kojarzone jedynie z wymiarem gospodarczym, jednak siła jego oddziaływania jest tak duża, że zaczęto dostrzegać kontekst kulturowy, polityczny oraz społeczny. Badacze przedmiotu utożsamiają rozwój procesów globalizacyjnych z postępem technologicznym. Anthony Giddens twierdzi, że siłą napędową omawianego zjawiska jest „rozwój technik informacyjnych i telekomunikacyjnych, który przyczynił się do wzrostu tempa i zakresu interakcji między ludźmi na całym świecie" ${ }^{\prime \prime}$. Odwołując się do słów Barrego Smarta, możemy stwierdzić, że rozwój technologii „zespolił świat niemalże w realnym czasie"10. Wydaje się, że jednym z największych nieszczęść mobilnej ludzkości byłoby pozbawienie jej dostępu do Internetu. Jan-Erik Lane zauważa, iż rozwój nowoczesnych technologii komunikacyjnych oraz Internetu przyczynia się w dużej mierze do budowania "globalnego otwartego społeczeństwa". Twierdzi, że upadek reżimów komunistycznych na początku lat dziewięćdziesiątych nastąpił nie tylko na skutek utraty legitymizacji ich władzy, ale także dzięki przepływowi informacji11.

\section{Młodzież a partycypacja społeczna}

Will Kymlicka, który przypisuje duże znaczenie cnotom obywatelskim, twierdzi, że w procesie ich kształtowania ważne jest nabywanie umiejętności krytycznej oceny władzy oraz angażowanie się w publiczny dyskurs dotyczący kwestii politycznych. Uważa on, że elementy te stanowią ważny czynnik w budowaniu i utrzymaniu liberalnej demokracji oraz mogą uchronić przed powstaniem reżimów ${ }^{12}$. Podnosi również kwestię umiejętności prowadzenia dialogu. Współcześnie demokracja, w opinii Kymlicka'ego, nie

8 A. Giddens, Życie w społeczeństwie posttradycyjnym, [w:] Modernizacja refleksyjna, red.

U. Beck, A. Giddens, S. Lash, Warszawa 2009, s. 129.

${ }^{9}$ A. Giddens, Socjologia, Warszawa 2000, s. 74.

10 B. Smart, Postmodernizm, Poznań 1998, s. 179.

${ }^{11}$ J.E. Lane, Globalization and politics. Promises and dangers, Hampshire 2006, s. 217.

12 W. Kymlicka, Contemporary political philosophy. An Introduction, Oxford 2002, s. 289. 
ogranicza się jedynie do prawa głosu, lecz również jest prawem do zabierania głosu'13. Debata publiczna staje się jednym z głównych elementów demokratycznego społeczeństwa. Podobne stanowisko w tej kwestii zabiera Warren A. Nord, który zauważa, że ograniczenie swobody wypowiedzi $\mathrm{w}$ debacie publicznej może być bardziej dotkliwe niż pozbawienie prawa do głosowania ${ }^{14}$. Z tej perspektywy rozwój technologii informacyjnych powinien ułatwiać wymianę poglądów i prowadzenie społecznego dialogu. Internet, w opinii badaczy przedmiotu, niweluje rzeczywiste nierówności społeczne. Na forach internetowych, portalach społecznościowych pochodzenie społeczne, rasa, płeć nie mają takiego znaczenia stratyfikacyjnego, jak w świecie rzeczywistym. Innymi słowy - w przestrzeni wirtualnej, każdy ma prawo głosu. W tym kontekście Kymlicka zauważa, że warunkiem uczestnictwa wszystkich grup społecznych w debacie publicznej jest rozwój demokracji debatującej. Istnieje bowiem przekonanie, że w jej obrębie mamy możliwość budowania bardziej sprawiedliwego, zjednoczonego i solidarnego społeczeństwa. Taka demokracja jest w stanie zapewnić wzajemne rozumienie, szacunek oraz poczucie obywatelskiej przyjaźni ${ }^{15}$. Być może, że za sprawą Internetu i wyłonieniem się e-demokracji więcej jednostek może zabrać głos w istotnych dla nich sprawach.

$\mathrm{Z}$ drugiej jednak strony, w wielu demokratycznych państwach obserwuje się wyraźny spadek uczestnictwa ludzi w życiu publicznym. Okazuje się, że młodzi ludzie stają się apatyczni „wiedzą mniej, głosują mniej, mniej się interesują i są mniej krytyczni wobec liderów politycznych i instytucji"16. Kwestię spadku zaangażowania w życie publiczne Amerykanów podjął Robert Putnam w publikacji Bowling Alone (Samotny kręglarz). Metafora samotnego bowlingu odnosi się do kondycji życia publicznego w Stanach Zjednoczonych. Putnam pokazuje, że Amerykanie są coraz mniej skłonni do angażowania się $\mathrm{w}$ stowarzyszenia, które przez pokolenia stanowiły rdzeń społeczności lokalnych i formę ekspresji wyznawanych przez nich wartości ${ }^{17}$.

W rozwiniętych społeczeństwach demokratycznych istnieją przynajmniej cztery obszary, które poprzez swoje oddziaływanie kształtują postawy obywatelskie jednostki. Will Kymilcka przypisuje duże znaczenie rynkowi. Uzasadnia on, że główną aktywnością ludzi jest zarabianie pieniędzy. Po-

13 Tamże, s. 290

14 W.A. Nord, Disagreement, moral education, common ground, [w:] Making good citizens. Education and civil society, red. D. Ravitch, J.P. Viteritti, New Haven-London 2001, s. 149.

15 Tamże.

16 Tamże.

17 Zob. R. Putnam, Bowling alone. The collapse and revival of American Community, New YorkLondon-Toronto-Sydney 2000. 
nadto, rynek kształtuje określone zachowania konsumenckie. Jednak ci, którzy nie są uczestnikami gry rynkowej - z powodu bezrobocia lub braku dostępu do dóbr konsumpcyjnych - mogą być zmarginalizowani i wykluczeni, bowiem „rynek uczy inicjatyw, jednak nie w kategoriach sprawiedliwości i społecznej odpowiedzialności"18. Drugim obszarem są organizacje oraz takie instytucje, jak: kościoły, rodziny, związki, stowarzyszenia, grupy sąsiedzkie itp. Zwolennicy społeczeństwa obywatelskiego przypisują im duże znaczenie w procesie kształtowania cnót i postaw obywatelskich. Kymlicka zauważa jednak, że organizacje te nie zawsze są w stanie wypełnić swoją misję odnośnie kreowania wspomnianych postaw. Często stają się zamknięte, dbające o swoje partykularne interesy. Ponadto, w opinii Kymlicka'ego, powody, dla których ludzie wstępują do tych organizacji nie zawsze wynikają z chęci uczenia się partycypacji w życiu społecznym i nabywania postaw obywatelskich. Kymlicka zauważa,

jeśli wierzy się, że rodzice lub ksiądz organizuje życie grup społecznych w celu maksymalnego promowania obywatelstwa, wówczas kwestionuje się podstawowe założenie istnienia tych organizacji ${ }^{19}$.

Trzecim obszarem, który wpływa zasadniczo na kształtowanie postaw obywatelskich jest dom rodzinny ${ }^{20}$. Jednak Kymlicka dostrzega ograniczony wpływ tych trzech obszarów na kształtowanie postaw obywatelskich. W jego opinii, czwarty obszar - system edukacyjny - jest w stanie sprostać wyzwaniom współczesnego świata w budowaniu odpowiedzialnej postawy obywatelskiej. Utrzymuje on, że szkoły są odpowiedzialne za kształtowanie moralności oraz za rozwój krytycznego myślenia, gdyż to one wpływają na rozwój poczucia odpowiedzialności w sferze publicznej. Mimo tego, że szkoły stają się często miejscem, w którym promowane są niedemokratyczne wartości, takie jak szowinizm, ksenofobia, to wielu badaczy przedmiotu utrzymuje, że mogą one zostać przeorganizowane, aby w efektywny sposób rozbudzać odpowiedzialność obywatelską ${ }^{21}$. Badania przeprowadzone w Stanach Zjednoczonych w połowie lat dziewięćdziesiątych potwierdzają, że system oświatowy ma współcześnie większy wpływ na aktywność polityczną młodych ludzi niż rodzina i instytucje religijne ${ }^{22}$. W tym kontekście należałoby dodać jeszcze jeden obszar, a mianowicie media. Mogą one kreować

${ }_{18}$ W. Kymlicka, Contemporary political philosophy, s. 304.

19 Tamże, s. 306.

20 Tamże.

${ }^{21}$ Tamże, s. 308.

${ }^{22}$ K. Spiezio, Engaging general education, [w:] Civic engagement in higher education. Concepts and practices, red. B. Jacoby and Associates, San Francisco 2009, s. 89. 
zarówno postawy obywatelskie, antyobywatelskie, a także jedynie konsumenckie. Dlatego, być może istotna jest współpraca oraz prowadzenie dialogu między aktorami wszystkich tych obszarów.

William Damon, jak też inni badacze przedmiotu, zauważa, że coraz więcej młodych ludzi wykazuje antyspołeczne postawy i unika partycypacji w życiu społecznym, którego najbardziej wymiernym wskaźnikiem jest spadek frekwencji w wyborach ${ }^{23}$. Sądzę, że zjawisko to nie dotyczy jedynie społeczeństwa amerykańskiego, ale większość społeczeństw zachodnich, w tym także polskiego. Na przykład, aktywność wyborcza Polaków, jak pokazuje frekwencja $\mathrm{w}$ wyborach, jest ciągle najniższa $\mathrm{w}$ porównaniu $\mathrm{z}$ innymi krajami postkomunistycznymi. Mikołaj Cześnik zauważa, że średnia frekwencja wyborcza Polaków wynosi 47,31\%. Dla porównania, w innych krajach byłego bloku wschodniego wynosi ona powyżej $60 \% 24$. Badania Cześnika ujawniają tendencję, o której piszą Damon i Putnam, a mianowicie niskiej frekwencji wyborczej wśród osób młodych. Osoby między 18. a 35. rokiem życia głosują rzadziej niż osoby w wieku średnim, a mianowicie od 36. do 65. roku życia (chociaż największy odsetek stanowi wśród grup między 46-55 i 56-65 lat)25. Warto również zauważyć za przywołanym badaczem, że w głosowaniu rzadziej biorą udział kobiety niż mężczyźni, co de facto koresponduje $\mathrm{z}$ ogólnoświatowym trendem, chociaż proporcje te, w opinii przywołanego badacza, zmniejszają się. Godną uwagi korelacją jest wykształcenie wyborców. Nie ulega wątpliwości, iż osoby z wyższym wykształceniem stanowią najwyższy odsetek wśród biorących czynny udział w wyborach. Na przykład, w $2007^{26}$ roku aż $90 \%$ osób należących do tej grupy zmobilizowało się do wzięcia udziału w wyborach ${ }^{27}$. W Polsce wciąż wskazuje się niski poziom zaufania obywateli względem siebie, jak i instytucji państwa, co jest związane z niskim kapitałem społecznym ${ }^{28}$. Bardziej aktualne raporty nadal wskazują na niską partycypację Polaków. Na przykład, raport z 2014 roku Instytutu Spraw Publicznych "Decydujmy razem” również wskazuje na niską aktywność obywatelską Polaków zarówno na

${ }^{23}$ W. Damon, To not fade away: restoring civil identity among the young, [w:] Making good citizens, s. 123-124.

${ }^{24}$ M. Cześnik, Partycypacja wyborcza Polaków, adres internetowy: http://www.isp.org.pl/ files/20145849250174351001263374709.pdf, [dostęp: 20.04.2012], s. 7.

25 Tamże, s. 18.

${ }^{26}$ Należy zauważyć, iż $\mathrm{w}$ wyborach tych trwała intensywna kampania społecznopolityczna, która w opinii autora Raportu mogła wpłynąć na te wyniki.

27 Tamże, s. 21.

28 Zob. M. Gumkowska i in., Indeks społeczeństwa obywatelskiego Polsce 2007, Warszawa 2008. 
poziomie lokalnym (samorząd), jak i krajowym. Anna Olech w przywołanym raporcie stwierdza, że

Polacy - w większości - są zainteresowani sprawami publicznymi swoich społeczności, ale nie uczestniczą w regulowaniu tych spraw, nie angażują się, a więc i nie korzystają z dostępnego zakresu wpływu i sprawstwa. Aktywność obywatelska znika w luce między „zainteresowaniem" a „zaangażowaniem”29.

Pomimo że w literaturze przedmiotu eksponowana jest zależność między edukacją a uczestnictwem w życiu obywatelskim, to i tak w ostatnich latach obserwuje się spadek zaangażowania obywateli w życiu publicznym. Osłabienie więzi społecznych w obrębie wspólnot lokalnych, czy nawet ich zanik na rzecz większej indywidualizacji jednostek, stanowi jedną z przyczyn spadku aktywności obywatelskiej. Z drugiej jednak strony, jak wskazują powyższe badania, wykształcenie jednostek wpływa na kształtowanie kapitału społecznego i podnosi zaangażowanie społeczne ludzi. Z tej perspektywy na instytucjach oświatowych spoczywa odpowiedzialność za kształtowanie takich postaw społecznych, które przeciwdziałają wykluczeniu i marginalizacji jednostek czy grup.

\section{Facebook jako współczesna agora (?) życia społeczno-politycznego}

Facebook wywołuje odczucia ambiwalentne: dla jednych osób jest on urzeczywistnieniem globalnej wioski, dla innych społecznej izolacji; dla jednych możliwością utrzymywania kontaktów towarzyskich, dla innych okazją do uwypuklenia własnego narcyzmu ${ }^{30}$. Przywołany wcześniej Marshall McLuhan utrzymywał, że każde nowe narzędzie komunikacji prowadzi do zmian społecznych ${ }^{31}$. Wydaje się, iż Facebook nie doprowadził do radykalnej zmiany społecznej, ale z całą pewnością zmienił obraz współczesnej komunikacji. Wykazuje on wszystkie cechy, które przypisywane są kategorii nowych mediów, a są nimi: cyfrowość, interaktywność, hipertekstualność, usieciowienie oraz wirtualność32. Facebook jest również doskonałą egzem-

${ }^{29}$ A. Olech, Między zainteresowaniem a zaangażowaniem - aktywność obywatelska i organizacje pozarządowe w Polsce, Analizy i Opinie - numer specjalny, 7 czerwiec 2014 - „Decydujmy razem", s. 3.

${ }^{30}$ Zob. Z. Melosik, Kultura popularna i tożsamość młodzieży, s. 239; D.E. Wittkower, A reply to Facebook critics, [w:] Facebook and Philosophy. What's on your mind, red. D.E. Wittkower, Chicago 2010, s. XXIII.

${ }^{31}$ Zob. M. McLuhan, Zrozumieć media. Przedtużenie człowieka, Warszawa 2004.

32 J. Nowak, Aktywność obywateli online. Teoria i praktyka, Lublin 2011, s. 16-18. 
plifikacją społeczeństwa sieciowego, bowiem używając słów Manuela Castellsa, doświadczenia czasu i przestrzeni zostały zastąpione ponadczasowością i przestrzenią przepływu. Ponadto, w społeczeństwie Sieci ludzie mogą $\mathrm{w}$ nieograniczony sposób, $\mathrm{z}$ użyciem technologii informacyjnych, wchodzić w liczne relacje w obrębie różnych grup interesów ${ }^{33}$.

Współczesne pokolenie młodzieży określane jest jako globalni nastolatkowie, milenijna generacja, cyfrowi imigranci lub cyfrowi rodacy. Podstawową kategorią przypisywaną młodym ludziom jest zdolność do życia $\mathrm{w}$ świecie nowoczesnych technologii, gdzie przepływ informacji, ludzi, usług i towarów odbywa się w sposób natychmiastowy. Pokolenie to, w odróżnieniu od starszej generacji, ma trudności w odróżnieniu tego, co dotychczas było postrzegane jako sfera prywatna a publiczna ${ }^{34}$. Hiperpubliczny rodzaj komunikacji nie jest postrzegany przez nich jako inwazja na prywatność, przeciwnie - wielu z nich widzi, że jest to najprostszy sposób komunikacji grupowej35. Młode pokolenie żyje między przestrzenią rzeczywistą a wirtualną, a granica oddzielająca obydwie sfery zaczyna się rozmywać. Ponadto, jak zauważa Del Siegle, to co zostaje opublikowane w Internecie, wychodzi poza przestrzeń prywatną, wkraczając $\mathrm{w}$ przestrzeń publiczną ${ }^{36}$. Warto dodać również, że każdy tekst (przyjmując założenie, że wszystko jest tekstem) w Internecie odrywa się od swojego twórcy, przestaje należeć jedynie do niego, staje się obiektem publicznym. Skutkiem braku rozróżnienia między tym co intymne a tym co publiczne jest brak jakiejkolwiek selekcji informacji, z którymi użytkownicy się dzielą. Według badań przeprowadzonych przez Kathernie Peluchette i Joy Karl, 42\% użytkowników Facebooka komentowało wydarzenia powiązane $\mathrm{z}$ alkoholem, $52 \%$ posiadało na swoim profilu zdjęcia, na których było widać jego spożycie, $20 \%$ dało komentarz powiązany z aktywnością seksualną, 25\% umieściło prowokacyjne zdjęcia o charakterze seksualnym, a w przypadku 50\% użytkowników dostrzec można było profanację ${ }^{37}$. Dzieje się tak, bowiem użytkownicy Facebooka nie dostrzegają wspomnianej granicy między przestrzenią publiczną a prywatną, sądząc, że treści, które publikują, pozostają pod ich kontrolą.

33 Zob. M. Castells, Społeczeństwo sieci, Warszawa 2007.

34 Por. C. Lego Muñoz, T.L. Towner, Opening Facebook: How to Use Facebook in the College Classroom, http://www46.homepage.villanova.edu/john.immerwahr/TP101/Facebook.pdf; [dostęp: 29.07.2013]; G. Lovink, Networks without a cause, Cambridge 2011, s. 39.

35 D. Siegle, Facing Facebook: A Guide for Nonteens, Gifted Child Today, 2011, 2, s. 15.

36 Tamże, s. 16.

${ }^{37}$ J. Peluchette, K. Karl, Examining students' intended image on Facebook: What were they thinking?! Journal of Education for Business, 2011, s. 30, podaję za: T.B. Crews, W.L. Stitt-Gohdes, Incorporating Facebook and Twitter in a Service-Learning Project in a Business Communication Course, Business Communication Quarterly, 2012, 75, s. 76-79. 
W świecie Internetu, jak zauważa Graham Meikle, prywatne życie ludzi w sposób natychmiastowy staje się życiem publicznym ${ }^{38}$. Należy również zauważyć, iż tożsamość w świecie wirtualnym ma charakter ekshibicjonistyczny. Portale społecznościowe nakazują swoim użytkownikom dzielenie się nawet najbardziej prywatnymi szczegółami życia. Bauman utrzymuje, że portale społecznościowe pełnią współcześnie funkcje przenośnych konfesjonałów,

a nasze społeczeństwo ma charakter spowiedniczego społeczeństwa, które z upodobaniem zaciera granicę dzielącą niegdyś rzeczy prywatne od publicznych, czyniącego cnotą i obowiązkiem publiczne obnażanie prywatności oraz usuwającego z publicznego przekazu wszystko, co nie daje się sprowadzić do poziomu prywatnych sekretnych wyznań i wszystkich tych, którzy nie zamierzają się z nimi podzielić39.

Z perspektywy tej, podążając za rozważaniami przywołanego autora, niewidoczność równa się ze śmiercią. To zdanie idealnie wpisuje się właśnie w kontekst funkcjonowania Facebooka. Jeśli użytkownik zaniecha działań, wówczas jego profil przestaje mieć rację bytu.

Zygmunt Bauman wielokrotnie w swych rozważaniach wskazywał, że współcześnie wspólnoty zamierają, a więzi, które je konstytuowały stają się słabe. $Z$ drugiej strony, wydaje się, iż dzięki takim portalom jak Facebook czy Twitter, z których możemy korzystać zawsze i wszędzie, o ile mamy dostęp do Internetu, pozostajemy w ciągłym kontakcie, ale też i współzależności z innymi. Facebook jest zatem przejawem kultury uczestniczącej. Tworzy się ona wtedy, kiedy poszczególni jej członkowie działają. Zamiera, jeśli nikt „nic nie robi”. W dobie nowoczesnych technologii wspólnota nie ogranicza się już jedynie do wymiaru terytorialnego, wychodzi w globalną przestrzeń, którą scalają wspólne interesy. Toteż, coraz częściej wskazuje się na istnienie wirtualnych wspólnot, które tworzą się głównie wokół wspólnych zainteresowań. $\mathrm{W}$ związku z powyższym apeluje się, aby poszukiwać nowych określeń dla więzi międzyludzkich, niż te, które były dotychczas wymienianie $\mathrm{w}$ literaturze przedmiotu ${ }^{40}$. W tym kontekście warto odwołać się do słów D.E. Wittkowera, który zauważa, że Facebook „jest w pewnym sensie zwierciadłem naszego społecznego bytu, a my nie zawsze cieszymy się ze wszystkich aspektów wspólnoty, do której przynależymy" ${ }^{41}$. Kultura,

38 G. Meikle, It's like talking to a wall, [w:] Facebook and Philosophy, s. 19.

${ }^{9}$ Z. Bauman, Konsumowanie życia, Kraków 2009, s. 9.

40 Zob. A. Kobylarek, Pomiędzy hipertekstem a hiperwięzia. O ksztattowaniu się nowych wspólnot sieciowych, [w:] Ponowoczesne konteksty edukacji, red. L. Jakubowska-Malicka, A. Kobylarek, M. Pryszmont-Ciesielska, Wrocław 2009, s. 137.

${ }^{41}$ D.E. Wittkower, A reply to facebook critics, s. XXIV. 
w której przyszło nam żyć nie jest zorientowana na mozolne budowanie więzi społecznych, bowiem pojawia się natychmiastowość relacji międzyludzkich, które nie są zorientowane na głębsze zaangażowanie się. Toteż, jak uczy nas Zygmunt Bauman, społeczeństwo konsumentów nastawione jest na nieprzerwaną gre „ „W podłączanie się i odłączanie do sieci oraz niekończący się ciąg połączeń i rozłączeń", które z kolei zastępują „determinację, przypisanie i przynależność" 42 . W odniesieniu do wspólnot wirtualnych Darin Barney dostrzega, że nie są one wspólnotami, a co najwyżej „pseudowspólnotami" 43 .

Jak zostało to wcześniej ukazane, żyjemy w czasach ekshibicjonistycznych, $\mathrm{w}$ społeczeństwie spowiedniczym, w których nowoczesne media pełnią funkcję konfesjonałów. Użytkownicy portali społecznościowych pozwalają siebie śledzić oraz mają możliwość śledzenia innych. Z tej perspektywy są one często przyrównywane do panoptykonu44. Odwołując się do Foucaulta, instytucje państwowe wykorzystują technikę panoptyzmu we wszystkich sferach życia. Co więcej, inwigilacja państwowa jest wszechobecna nawet $\mathrm{w}$ ustrojach demokratycznych, a przykładem może być umieszczanie kamer na ulicach ${ }^{45}$. Zatem, teza Foucaulta odnośnie permanentnej inwigilacji w dobie nowoczesnych mediów wydaje się jak najbardziej aktualna. Należy jednak zauważyć, iż użytkownicy portali społecznościowych sami dają przyzwolenie, aby być poddawanymi permanentnej inwigilacji. Jeśli przyjmiemy, iż Facebook jest pewnym rodzajem wspólnoty, to należy zwrócić uwagę, iż w tradycyjnych społecznościach istnieje zjawisko kontroli, autorytetu i władzy, a w konsekwencji tworzy się hierarchia. Członkowie facebookowej wspólnoty są równi, a władza i autorytet ulegają rozmyciu ${ }^{46}$. Waddick Doyle i Matthew Foster uważają, że z perspektywy Folucaulta, Facebook nie może być przestrzenią, w której zanika hierarchia. Według Foucaulta, komunikacja jest zawsze przedmiotem "gry o władzę", dlatego nigdy nie może być „równa, egalitarna i otwarta", nie istnieje wolna sfera komunikacji, bowiem zawsze mamy do czynienia z permanentną inwigilacją ${ }^{47}$. Foucault twierdził, że władza nie ogranicza się jedynie do państwa narodowego, ale rozprasza się na różne instytucje. $Z$ tej perspektywy Waddick Doyle i Matthew Foster twierdzą, że dla Foucaulta Facebook byłby platformą rozproszonej władzy, ponieważ oferuje on ludziom kategorie, w ra-

42 Z. Bauman, Kultura w ptynnej nowoczesności, s. 28.

43 D. Barney, Społeczeństwo sieci, Warszawa 2008, s. 184.

${ }^{44}$ W. Doyle, M. Fraser, Facebook, surveillance and power, [w:] Facebook and Philosophy, s. 217.

45 Tamże.

${ }^{46}$ A. Fairweather, J. Halpern, Do status updates have any value? [w:] Facebook and Philosophy, s. 197.

47 Tamże. 
mach których mogą siebie definiować, a dzięki temu określać, co jest prawdziwe ${ }^{48}$. W świecie Facebooka, z jednej strony „uwalniamy siebie”, określając kim jesteśmy, ale z drugiej strony jesteśmy poddawani kontroli i ocenie. Ludzie manifestujący swoje poglądy na Facebooku często są nieświadomi, iż stają się obiektem kontroli. Z tej perspektywy koncepcja panoptykonu wpisuje się w funkcjonowanie mediów społecznościowych ${ }^{49}$. Toteż, jak zauważa Henry R. Lewis, technologie cyfrowe

są najbardziej efektywnymi narzędziami rozprzestrzeniania się wiedzy, jakie kiedykolwiek wynaleziono, ale są też najlepszymi narzędziami monitorującymi ich zawartość. Świat cyfrowych technologii jest światem kontroli50.

Warto zauważyć, że dzięki nowym mediom pojawia się nowy rodzaj aktywności obywatelskiej, nazywany cyberaktywizmem, e-mobilizacją, czy haktywizmem. Zmienia się zatem obraz funkcjonowania współczesnych społeczeństw demokratycznych, operuje się pojęciami „teledemokracji”, a w kontekście poruszanego problemu można wprowadzić termin „facebookracji”. Jakub Nowak zauważa, iż

wraz z rozwojem i upowszechnieniem nowych mediów następuje proces powiększenia się wymiaru demokratycznej debaty i partycypacji, co sprzyja powstawaniu nowych publicznych przestrzeni obywatelskiej aktywności ${ }^{51}$.

Można zatem postawić tezę, aczkolwiek na tym etapie należy podejść do jej weryfikacji z dużą ostrożnością, że media społecznościowe pomagają ludziom jednoczyć się, tworząc wirtualne grupy interesów, które dzięki wspólnemu celowi przenoszą swoje działania do świata rzeczywistego. Badania przeprowadzone przez Homero Gil de Zuniga i Sebastaian Valenzuela wskazują, że wiele osób korzysta z Facebooka jako źródła informacji, a także przypisują mu możliwość zwiększenia uczestnictwa w życiu społecznym². Michele Zappavigna, która w swych badaniach skoncentrowała się na roli Twittera w aktywności politycznej obywateli, zauważa, że współcześnie „obywatele używają mediów społecznościowych w celu wyrażania politycznych poglądów oraz zabierania głosu w dyskusji z innymi użytkowni-

48 W. Doyle, M. Fraser, Facebook, surveillance and power, s. 227.

${ }^{49}$ Tamże, s. 228.

${ }^{50}$ H.R. Lewis, The Internet and Hieronymus Bosch: Fear, protection, and liberty in cyberspace, [w:] The Harvard Sampler. Liberal education for XXI century, red. J.M. Shephard, S.M. Kosslyn, E.M. Hammands, Harvard 2011, s. 59.

51 J. Nowak, Aktywność obywateli online, s. 75.

${ }^{52}$ H. Gil de Zuniga, S. Valenzuela, Who uses facebook and why? [w:] Facebook and Philosophy, s. XXXVI. 
kami sieci"53. Na skutek rozwoju mediów społecznościowych obserwuje się powstanie tzw. dziennikarstwa obywatelskiego (citizen journalism), czyli dziennikarstwa uprawianego przez zwykłych obywateli $\mathrm{w}$ interesie społecznym ${ }^{54}$.

Należy zauważyć, iż za sprawą Facebooka jako narzędzia masowej komunikacji można zwrócić uwagę użytkowników na ważne kwestie społeczno-polityczne. Oto 18-letnia Michelle Ryan Lauto za pomocą Facebooka rozpoczęła kampanię przeciwko cięciom budżetowym $\mathrm{w}$ oświacie $\mathrm{w}$ New Jersey. Wysłała wiadomość do 600 swoich znajomych, zachęcając do protestów wobec decyzji władzy. 18000 osób dołączyło do jej kampanii w ciągu kilku tygodni ${ }^{55}$. W mediach amerykańskich można było spotkać się z opinią, iż takie działania budują społeczeństwo obywatelskie, a Internet stał się doskonałym narzędziem w promowaniu postaw obywatelskich. Konsekwencją protestu na Facebooku była mobilizacja młodych ludzi w świecie rzeczywistym, którzy wyszli na ulice, aby przeciwstawić się propozycjom cięć budżetowych ${ }^{56}$. Siła Facebooka wskazuje na jeszcze jeden aspekt - na możliwość oddolnych inicjatyw, które są zgłaszane przez osoby, którym w świecie rzeczywistym trudniej zabrać głos, na przykład młodzieży. Niestety, odpowiedź władz na protesty młodzieży sprowadziła się do lakonicznego stwierdzenia, że powinni oni być $\mathrm{w}$ tym czasie w szkole, a nie na ulicach. Jednocześnie przedstawiciel lokalnej władzy zaapelował do nauczycieli i dyrekcji szkół, aby zaostrzyli politykę sprawdzania obecności i nie pozwalali uczniom na udział w proteście ${ }^{57}$.

Warto również przywołać protest na Krakowskim Przedmieściu w Warszawie w 2010 roku. Odwołuję się do tego przykładu nie ze względu na cel protestu (usunięcie tzw. krzyża smoleńskiego sprzed pałacu prezydenckiego), lecz ze względu na uwypuklenie siły Facebooka jako narzędzia ułatwiającego samomobilizację obywateli. Oto bowiem jeden z internautów za pomocą Facebooka zorganizował protest, do którego w świecie wirtualnym dołączyło się ponad sześć tysięcy użytkowników. Na manifestację przybyło, według różnych źródeł, około tysiąca osób. Warto zwrócić uwagę na dwa istotne aspekty tego wydarzenia. Po pierwsze, protest zorganizowała osoba prywatna, do czasu odbycia się wydarzenia anonimowa, nie powiązana z żadną organizacją czy partią polityczną. Większość zbiorowych protestów

53 M. Zappavigna, Discourse of Twitter and social media, London 2012, s. 170.

54 Tamże, s. 172.

${ }^{55}$ http://www.nj.com/news/index.ssf/2010/04/facebook_student_protest_mobilize. html

56 W. Hu, In New Jersey, a Civics Lesson in the Internet Age, "New York Times" z 27.10.2010, http://www.nytimes.com/2010/04/28/nyregion/28jersey.html?_r=0 [dostęp: 12.01.2015].

57 Tamże. 
było przeważnie organizowanych przez formalne organizacje o charakterze polityczno-społecznym, a ich celem była realizacja partykularnych interesów. Po drugie, powyższy przykład ukazuje, iż dzięki Internetowi oraz jego narzędziom w sposób łatwy i szybki można zmobilizować ponad sześć tysięcy osób, które nie pozostają $\mathrm{w}$ żadnej relacji między sobą, poza relacją sieciową. $Z$ tej perspektywy Facebook pozwala na oddolne organizowanie się społeczeństwa obywatelskiego, ułatwia i usprawnia proces komunikacji między ludźmi. Aczkolwiek przywołany przykład pokazuje również, iż władza, a tym samym odpowiedzialność ulega rozproszeniu za organizowanie tego typu działań. Skoro władza, przywództwo i odpowiedzialność ulegają rozproszeniu, w sposób nieuchronny może to prowadzić do chaosu, a chaos nie sprzyja ani demokracji, ani społeczeństwu obywatelskiemu. Jako przykład warto $\mathrm{w}$ tym miejscu przywołać sprawę 23-letniej studentki, która za pomocą Facebooka zorganizowała nielegalne ognisko, w którym uczestniczyło ponad 20 tysięcy uczestników. Sprawa zakończyła się w sądzie, a studentka została uznana za winną i skazana na karę grzywny ${ }^{58}$. Powyższy przypadek pokazuje, iż Facebook może być doskonałym narzędziem do komunikacji międzyludzkiej, o ile ma się nad nim kontrolę. Utrata kontroli nad wydarzeniem, które zaczyna „żyć swoim własnym życiem” w Sieci jest bardzo łatwe, bowiem ostatecznie Facebook dla wielu jego użytkowników jest jedynie formą rozrywki, przykładem "poważnej zabawy", jak ujął to Henry Jenkins 59 .

W chwili pisania tego artykułu, wielu użytkowników Facebooka przyłączyło się do akcji wyrażającej solidarność z ofiarami zamachu na redakcję francuskiego czasopisma "Charlie Hebdo". Internauci zamieszczają zdjęcia z napisem "Je suis Charlie", wyrażając tym samym jedność przeciwko zamachowi na wolność słowa. Nie do końca wyjaśniony został mechanizm powielania przez użytkowników pewnych zachowań i treści. To powielanie zostało określone jako „viral”, a zatem rozprzestrzenianie się jakiegoś postu przypomina rozprzestrzenianie się wirusa ${ }^{60}$.

Warto w tym miejscu odnieść się do eksperymentu przeprowadzonego w Stanach Zjednoczonych w czasie wyborów do Kongresu w 2012 roku, którego wyniki zostały opisane na łamach „Nature". Wysłano wiadomość o treści mobilizującej do wzięcia udziału w wyborach do 61 milionów użyt-

58 http:/ / wiadomosci.onet.pl/krakow/ kara-za-impreze-dla-20-tys-osob-mam-zal-zemalo-kto-mnie-wspieral/bj8ep

${ }^{59}$ Zob. D. Hejwosz-Gromkowska, Kultura natychmiastowości i konstruowanie tożsamości aktorów życia społecznego, [w:] Rekonstrukcje tożsamości w kulturze natychmiastowości, red. D. Hejwosz-Gromkowska, Poznań 2014.

${ }^{60}$ Zob. http://henryjenkins.org/2009/02/if_it_doesnt_spread_its_dead_p.html 
kowników Facebooka. Założono aplikację, która pozwoliła użytkownikom na kliknięcie klawisza "Głosowałem”. Wyniki pokazały, że wiadomość ta bezpośrednio wpłynęła na polityczną samoekspresję, na poszukiwanie informacji oraz na zachowania polityczne w świecie realnym. Co więcej, eksperyment ten pokazał również, że wiadomość ta rozprzestrzeniła się dalej, do znajomych i znajomych znajomych na Facebooku. Twórcy eksperymentu uważają, iż teza o słabych więziach społecznych na portalach społecznościowych została postawiona przedwcześnie. Ich eksperyment dowodzi, że komunikacja online i więzi społeczne w zakresie mobilizacji wyborczej mogą być tak samo skuteczne, jak komunikacja bezpośrednia ${ }^{61}$.

Powyższe przykłady pokazują, iż Facebook jako portal społecznościowy, u którego podstaw leży komunikowanie się z innymi odbiorcami, może służyć jako narzędzie samomobilizacji i komunikacji społecznej. Warto zauważyć w kontekście wyżej przedstawionych przykładów, iż Facebook pełni funkcje typowe dla mediów:

1) informacyjną (dostarcza różnorodnych treści w sposób natychmiastowy; budzi zainteresowanie i ciekawość; pozwala na przekazywanie i zdobywanie wiedzy, ale także wprowadza chaos informacyjny, dezorientację, pozorność rzetelności przekazywanych treści);

2) mobilizującą do określonych działań społecznych w Internecie oraz w świecie rzeczywistym, jak np. protesty, wiece poparcia (podnosi świadomość obywatelską na temat istotnych wydarzeń społeczno-politycznych, pozwala na wyrażenie własnych opinii, zachęca do działania obywatelskiego i społecznego, zwiększa proces komunikacji społecznej, ale także wprowadza możliwość prowadzenia mowy nienawiści, szkalowania, bezmyślnych i szkodliwych działań, a nawet terroru);

3) emocjonalną, interpersonalną (pozwala na autoekspresję, wyrażanie poglądów na tematy polityczne i społeczne, angażowanie się $\mathrm{w}$ dyskusję, ale także może prowadzić do izolacji i frustracji, przemocy werbalnej);

4) ludyczną (poprawia samopoczucie, daje możliwość zabawy, bycia w kontakcie ze znajomymi, ale także może prowadzić do osłabiania autentycznych przeżyć, izolowania się, „zabijania” czasu).

Badania pokazują, że Internet, a wraz z nim media społecznościowe mogą stać się narzędziem w budowaniu społeczeństwa obywatelskiego oraz przyczynić się do wzrostu lub umacniania kapitału społecznego. Jak twierdzą Marta Wronka i Hanna Saryusz-Wolska,

${ }^{61}$ R.M. Bond i in., A 61-million-person experiment in social influence and political mobilization, Nature, 13 September 2012, 489, s. 295-298. 
kontakty społeczne, które są konieczne do tworzenia kapitału społecznego, przenoszą się obecnie często do Internetu lub przynajmniej są tam kontynuowanie. Portale społecznościowe są przestrzenią, w której ludzie tworzą swój kapitał społeczny onli$n e$, a także podtrzymują tradycyjne relacje społeczne ${ }^{62}$.

Z kolei, amerykański raport Participatory Politics: New Media and Youth Political Action, autorstwa Cathy Cohen i Josepha Kahne, wskazuje, że młodzi ludzie, niezależnie od pochodzenia społecznego i przynależności rasowej/etnicznej, coraz częściej angażują się w działalność polityczną poprzez uczestnictwo w grupach dyskusyjnych online, aktywność na blogach politycznych, czy przesyłanie filmów wideo o charakterze politycznym. Autorzy Raportu zwracają uwagę, iż współczesna komunikacja polityczna jest interaktywna, rówieśnicza i ma charakter inkluzyjny, gdyż nie podlega kontroli ze strony elit lub formalnych instytucji63. Według przywołanego Raportu, $45 \%$ respondentów przyznało, że otrzymują informację co najmniej raz $\mathrm{w}$ tygodniu od swoich znajomych lub rodziny za pośrednictwem mediów społecznościowych, takich jak Twitter czy Facebook. Natomiast 49\% stwierdziło, że informacje czerpie z gazet. Młodzi ludzie przyznali również, iż chcieliby nauczyć się, w jaki sposób rozróżniać w przestrzeni Internetu źródła wiarygodne od niewiarygodnych ${ }^{64}$. Jest to niezwykle ważne zadanie dla pedagogów (a także dla nauczycieli akademickich, promotorów), aby uczyli swoich uczniów i studentów, w jaki sposób korzystać z Internetu oraz jak oddzielać informacje rzetelne od nierzetelnych. Ponadto, Facebook czy inne media społecznościowe nie mogą być traktowane przez pedagogów oraz rodziców jedynie jako źródło rozrywki i marnotrawienia czasu. Przeciwnie, jest to doskonała okazja, aby pokazać młodym ludziom, jak właściwie używać tego typu narzędzia w procesie komunikacji oraz zdobywania informacji. Pokazywać, które zachowania są negatywne, przy jednoczesnym wzmacnianiu zachowań pozytywnych. Innymi słowy, ukazywać przykłady, które obrażają innych, wykorzystują język nienawiści i wyjaśniać, iż ten sposób komunikacji nie jest akceptowany społecznie, bowiem obraża innych ludzi. Jednocześnie wskazywać, iż taka postawa jest niezgodna z obowiązującym prawem i może wiązać się z odpowiedzialnością prawną. Tego typu zajęcia mogą również dostarczyć wiedzy z zakresu tego, czym jest ochrona

${ }^{62}$ M. Wronka, H. Saryusz-Wolska, Wykorzystanie mediów społecznościowych do budowania kapitatu społecznego, [w:] Wykorzystanie nowych mediów w public relations, red. J. Gołuchowski, A. Frąckiewicz-Wronka, Katowice 2013, s. 51.

${ }^{63}$ C. Cohen, J. Kahne, Participatory politics. New media and youth political action, 2012, adres interentowy: http://ypp.dmlcentral.net/sites/default/files/publications/Participatory_Politi cs_Report.pdf [dostęp: 3.04.2015].

64 Tamże. 
danych osobowych oraz ochrona praw autorskich. To właśnie szkoła już od najmłodszych lat powinna uczyć, iż umieszczanie osobistych informacji o osobach trzecich oraz wizerunku bez ich zgody jest działaniem bezprawnym.

Z drugiej strony, warto pokazywać młodym ludziom, iż Facebook oraz inne media społecznościowe mogą wspomóc proces komunikacji i obywatelskiego zaangażowania. Należałoby zatem wprowadzać zajęcia z wykorzystaniem mediów społecznościowych do przestrzeni szkolnej i akademickiej. Może to być pierwszy krok w kształtowaniu tzw. „cyfrowego obywatelstwa” oraz tworzeniu przestrzeni dla odpowiedniego użycia technologii. Jeśli młodym ludziom nie dostarczy się wiedzy i umiejętności z zakresu właściwego korzystania z Internetu oraz mediów społecznościowych, wówczas istnieje ryzyko wykształcenia bezrefleksyjnych obywateli. W dzisiejszym, zdominowanym przez technologie świecie, obok nauki czytania, liczenia, rozumienia itp., ważne jest również umiejętne korzystanie z mediów społecznościowych. To przecież one stają się główną przestrzenią komunikacyjną młodych ludzi. Osoby odpowiedzialne za edukację nie mogą zapominać lub nie dostrzegać, że media społecznościowe są jedynie obszarem aktywności pozaszkolnej. Przeciwnie, one muszą stać się częścią życia szkolnego, programów edukacyjnych i wychowawczych. Wnioski z badań przeprowadzonych przez Scotta T. Millera wskazują, że studenci, którzy regularnie angażowali się w dyskusje na Facebooku mają większe poczucie obecności społecznej oraz większe poczucie uczenia się ${ }^{65}$. Konieczne wydaje się zrozumienie funkcji Facebooka. Sprowadzenie jego jedynie do kategorii czysto rozrywkowej - świetle ostatnich badań - jest dużym uproszczeniem. Z drugiej jednak strony, nie ma dowodów, iż stał się on współczesną agorą wymiany doświadczeń obywatelskich. Prawdopodobnie z Facebookiem jest tak, że dla każdego jego użytkownika pełni on różne funkcje. Dla jednych będzie on doskonałym miejscem dla pielęgnowania swojego narcyzmu, dla innych platformą ułatwiającą komunikację z przyjaciółmi i rodziną, a jeszcze dla innych - miejscem, w którym dzielą się informacjami i zachęcają do określonych działań ${ }^{66}$.

$\mathrm{Na}$ zakończenie warto odnieść się do spostrzeżeń B. Barbera, który twierdzi, że w sytuacji radykalnej zmiany jakiekolwiek uogólnienia na temat nowych mediów, wspólnoty, demokracji i społeczeństwa obywatelskiego

${ }^{65}$ S.T. Miller, Increasing Student Participation in Online Group Discussions Via Facebook, Astronomy Education Review, 2013, 12(1), s. 8.

${ }^{66}$ Por. Chia-chen Yang, B. Bradford Brown, Motives for Using Facebook, Patterns of Facebook Activities, and Late Adolescents' Social Adjustment to College, Journal Youth Adolescence, 2013, 42, s. 403-416. 
mogą nie przetrwać do dnia następnego ${ }^{67}$. Niewątpliwie, Facebook stał się potężnym narzędziem we współczesnej komunikacji. Jednakże, należy przewidywać, iż niedługo przestanie on być wystarczającym instrumentem, bowiem w kulturze natychmiastowości, konsumpcji oraz radykalnej zmiany w zakresie nowoczesnych technologii musi pojawić się kolejny portal, który zastąpi Facebooka. Aby tak się stało, to nowe zjawisko musi być inne tak, aby wzbudzić zainteresowanie znudzonych Facebookiem użytkowników. Zanim jednak tak się stanie, konieczne jest prowadzenie edukacji, której celem będzie kształtowanie odpowiednich postaw obywatelskich zarówno w świecie realnym, jak i wirtualnym. Edukatorzy, pedagodzy, rodzice, ale również świat akademicki nie powinien traktować Facebooka jedynie jako źródła rozrywki i zabawy. Jeśli edukacja z użyciem mediów społecznościowych jest możliwością dla kształtowania postaw obywatelskich, powinna stawać się również koniecznością.

\section{BIBLIOGRAFIA}

Barber B., Skonsumowani. Jak rynek psuje dzieci, infantylizuje dorostych i potyka obywateli, Warszawa 2008.

Barber B., The ambiguous effects on digital technology in a globalizing world, www. Wissensgesellschaft.org.

Barney D., Społeczeństwo sieci, Warszawa 2008.

Bauman Z., Globalizacja. I co z tego dla ludzi wynika, Warszawa 1999.

Bauman Z., Płynne życie, Kraków 2007.

Bauman Z., Wspólnota. W poszukiwania bezpieczeństwa w niepewnym świecie, Kraków 2008.

Bauman Z., Konsumowanie życia, Kraków 2009.

Bond R.M. i in., A 61-million-person experiment in social influence and political mobilization, Nature, 13 september 2012, 489.

Castells M., Społeczeństwo sieci, Warszawa 2007.

Cohen C., Kahne J., Participatory politics. New media and youth political action, 2012, adres interentowy: http://ypp.dmlcentral.net/sites/default/files/publications/Partici patory_Politics_Report.pdf [dostęp: 3.04.2015]

Crews T.B., Stitt-Gohdes W.L., Incorporating Facebook and Twitter in a Service-Learning Project in a Business Communication Course, Business Communication Quarterly, 2012, 75.

Cześnik M., Partycypacja wyborcza Polaków, Instytut Spraw Publicznych, adres internetowy: http:/ / www.isp.org.pl/files/20145849250174351001263374709.pdf, [dostęp: 20.04.2012].

Damon W., To not fade away: restoring civil identity among the young, [w:] Making good citizens. Education and civil society, red. D. Ravitch, J.P. Viteritti, New Haven-London 2001.

${ }^{67}$ B.R. Barber, The ambiguous effects on digital technology in a globalizing world, www. Wissensgesellschaft.org. 
Doyle W., Fraser M., Facebook, surveillance and power, [w:] Facebook and Philosophy. What's on your mind, red. D.E. Wittkower, Chicago 2010.

Fairweather A., Halpern J., Do status updates have any value? [w:] Facebook and Philosophy. What's on your mind, red. D.E. Wittkower, Chicago 2010.

Freishtat R.L., Sandlin J.A., Shaping Youth Discourse About Technology: Technological Colonization, Manifest Destiny, and the Frontier Myth in Facebook's Public Pedagogy, Educational Studies, 2010, 46.

Giddens A., Socjologia, Warszawa 2000.

Giddens A., Życie w społeczeństwie posttradycyjnym, [w:] Modernizacja refleksyjna, red. U. Beck, A. Giddens, S. Lash, Warszawa 2009.

Gil de Zuniga H., Valenzuela S., Who uses facebook and why? [w:] Facebook and Philosophy. What's on your mind, red. D.E. Wittkower, Chicago 2010.

Gumkowska M. i in., Indeks społeczeństwa obywatelskiego Polsce 2007, Warszawa 2008.

Hejwosz-Gromkowska D., Kultura natychmiastowości i konstruowanie tożsamości aktorów życia społecznego, [w:] Rekonstrukcje tożsamości w kulturze natychmiastowości, red. D. Hejwosz-Gromkowska, Poznań 2014.

Hejwosz-Gromkowska D. (red.), Rekonstrukcje tożsamości w kulturze natychmiastowości, Poznań 2014.

Hu W., In New Jersey, a Civics Lesson in the Internet Age, "New York Times" z 27.10.2010, http://www.nytimes.com/2010/04/28/nyregion/28jersey.html?_r=0 [dostęp: 12.01.2015].

Kobylarek A., Pomiędzy hipertekstem a hiperwięzią. O kształtowaniu się nowych wspólnot sieciowych [w:] Ponowoczesne konteksty edukacji, red. L. Jakubowska-Malicka, A. Kobylarek, M. Pryszmont-Ciesielska, Wrocław 2009.

Kymlicka W., Contemporary political philosophy. An Introduction, Oxford 2002

Lampe C., Wohn D.Y., Vitak J., Ellison N.B, Wash R., Student use of Facebook for organizing collaborative classroom activities, Computer-Supported Collaborative Learning, 2011, 6.

Lane J.E., Globalization and politics. Promises and dangers, Hampshire 2006.

Lego Muñoz C., Towner T.L., Opening Facebook: How to Use Facebook in the College Classroom, http://www46.homepage.villanova.edu/john.immerwahr/TP101/Facebook. pdf; [dostęp: 29.07.2013].

Lewis H.R., The Internet and Hieronymus Bosch: Fear, protection, and liberty in cyberspace, [w:] The Harvard Sampler. Liberal education for XXI century, red. J.M. Shephard, S.M. Kosslyn, E.M. Hammands, Harvard 2011.

Lovink G., Networks without a cause, Cambridge 2011.

McLuhan M., Zrozumieć media. Przedłużenie człowieka, przekł. N. Szczucka, Warszawa 2004.

Meikle G., It's like talking to a wall, [w:] Facebook and Philosophy. What's on your mind, red. D.E. Wittkower, Chicago 2010.

Melosik Z., Teoria i praktyka edukacji wielokulturowej, Kraków 2007.

Melosik Z., Kultura popularna i tożsamość młodzieży. W niewoli władzy i wolności, Kraków 2013.

Miller S.T., Increasing Student Participation in Online Group Discussions Via Facebook, Astronomy Education Review, 2013, 12(1).

Nord W.A., Disagreement, moral education, common ground, [w:] Making good citizens. Education and civil society, red. D. Ravitch, J.P. Viteritti, New Haven-London 2001.

Nowak J., Aktywność obywateli online. Teoria i praktyka, Lublin 2011. 
Olech A., Między zainteresowaniem a zaangażowaniem - aktywność obywatelska i organizacje pozarzadowe w Polsce, Analizy i Opinie - numer specjalny, 7 czerwiec 2014 - „Decydujmy razem".

Peluchette J., Karl K., Examining students' intended image on Facebook: What were they thinking?! Journal of Education for Business, 2011.

Putnam R., Bowling alone. The collapse and revival of American Community, New YorkLondon-Toronto-Sydney 2000.

Rosa H., Social acceleration. A New theory of modernity, przekł. J. Trejo-Methys, New YorkChichester-West Sussex 2013.

Siegle D., Facing Facebook: A Guide for Nonteens, Gifted Child Today, 2011, 2.

Smart B., Postmodernizm, Poznań 1998.

Spiezio K., Engaging general education, [w:] Civic engagement in higher education. Concepts and practices, red. B. Jacoby and Associates, San Francisco 2009.

Wittkower D.E., A reply to Facebook critics, [w:] Facebook and Philosophy. What's on your mind, red. D.E. Wittkower, Chicago 2010.

Wronka M., Saryusz-Wolska H., Wykorzystanie mediów społecznościowych do budowania kapitatu społecznego, [w:] Wykorzystanie nowych mediów w public relations, red. J. Gołuchowski, A. Frąckiewicz-Wronka, Katowice 2013.

Yang Chia-chen, Bradford Brown B., Motives for Using Facebook, Patterns of Facebook Activities, and Late Adolescents' Social Adjustment to College, Journal Youth Adolescence, $2013,42$.

Zappavigna M., Discourse of Twitter and social media, London 2012.

http://www.nj.com/news/index.ssf/2010/04/facebook_student_protest_mobilize.html http://wiadomosci.onet.pl/krakow/kara-za-impreze-dla-20-tys-osob-mam-zal-ze-malokto-mnie-wspieral/bj8ep

http://henryjenkins.org/2009/02/if_it_doesnt_spread_its_dead_p.html 